Papers and Proceedings of the Royal Society of Tasmania, Volume 111, 1977.

(ms. received 30.9 .1976$)$

\title{
LATE QUATERNARY FAN GRAVELS AND SLOPE DEPOSITS AT ROCKY CAPE, NORTHWESTERN
}

\section{TASMANIA : THEIR PALAEOENVIRONMENTAL SIGNIFICANCE}

\author{
by Eric A. Colhoun \\ Department of Geography, University of Tasmania \\ (with two tables, four text figures and two plates)
}

\section{ABSTRACT}

The paper describes a sequence of stratified quartzite slope deposits and alluvial fan gravels from a small catchment at Rocky Cape.

A lower series of indurated slope deposits overlain by a podzol soil profile suggests that cold climatic conditions, which favoured frost fracturing of exposed rock surfaces and gelifluction of detritus, occurred prior to the Last Glacial Stage. An upper series of unconsolidated slope deposits contains wedge structures. These deposits appear to have resulted from frost fracturing and to have been moved downslope by gelifluction processes. The wedge structures may have been produced by seasonal freezing of the ground surface during the period of maximum cold in the Last Glacial Stage (after 22,000 and before 10,000 BP).

Radiocarbon dating of charcoal and wood from organic horizons and a buried soil in the lower part of a thick sequence of alluvial fan gravels shows that they began to accumulate mainly between about 33,000 and 22,000 BP, when strong but episodic erosion of the open Eucalyptus forested catchment occurred. The upper part of the alluvial fan gravels does not contain organic horizons but probably accunulated after 22,000 and before 10,000 BP. The gravels were largely derived from the upper series of slope deposits which were formed in a non-forested environment.

\section{INTRODUCTION}

The Late Quaternary fan gravels and slope deposits to be described in this paper are exposed in three small quarries within the Rocky Cape Vational Park in northwestern Tasmanja (Long. $145^{\circ} 30^{\prime} \mathrm{E}$; Lat. $40^{\circ} 53^{\prime} \mathrm{S}$ ) (fig. 1). The quarries occur within a $2 \mathrm{~km}$ catchment that faces northwestwards and has slopes of $15-30$ degrees inclination. The exposures show the relationships between the slope deposits of the upper catchment and the large accumulation of fan gravels at the valley mouth.

The exposed sections reveal two distinct series of slope deposits; a lower indurated series and an upper unconsolidated series that are clearly separated by the development of a podzol soil profile on the lower series. The sections exposed in Quarry 1 reveal a series of organic-rich horizons within the lower part of the fan gravels, which also contain charcoal and wood fragments. One of the organic horizons forms part of an undisturbed palaeosol with roots in growth position. No organicrich horizons, wood fragments or palaeosols were observed in the upper part of the sequence of fan gravels, but some finely divided charcoal occurs near the surface of the deposits. The fan gravels and slope deposits are overlain by deposits of peaty sand.

Study of the morphology and stratigraphy of these landforms and deposits, analysis of the pollen contained in the organic horizons, and ${ }^{1 / C} \mathrm{C}$ dating gives some glimpses of the changing geomorphological processes and palaeoenvironmental conditions that affected this locality cluring the Jate Quaternary. Unfortunately the evidence from this site is fragmentary and the time record is discontinuous. The significance of the 
data can on $1 y$ be evaluated in conjunction with geomorphological and palaeoenvironmental evidence which is becoming available for other locations in Tasmania (Colhoun $1975 \mathrm{a}, 1976,1977 \mathrm{a}, 1977 \mathrm{~b}, 1977 \mathrm{c})$. This paper, therefore, presents the local evidence from Rocky Cape and suggests an interpretation of the geomorphological and pa1aeoenvironmental changes that have probably occurred.

\section{MORPHOLOGY, STRATIGRAPHY AND SEDIMENTS}

The Rocky Cape peninsula is composed of unmetamorphosed quartzites of Precambrian age which occur on the axis of the northeast trending Rocky Cape Geanticline (Banks 1965). The peninsula is characterised by a ridge of hills of similar trend which vary between $250 \mathrm{~m}$ and $300 \mathrm{~m}$ in height. The ridge is dissected into numerous small river basins with steep slopes on the middle and lower parts of which deposits of angular quartzite fragments have accumulated. Small tors occur on and near the sumits of the main ridge and minor interfluves.

The slopes of the river basin vary from about 15 to 30 degrees. The upper slopes have straight profiles developed on rock. The middle and lower slopes are mantled with quartzite detritus and decline towards the axis of the stream and the apex of the alluvial fan (fig. 1). The slope deposits grade into alluvial fan gravels, the surface of which slopes seawards at 5 to 10 degrees.

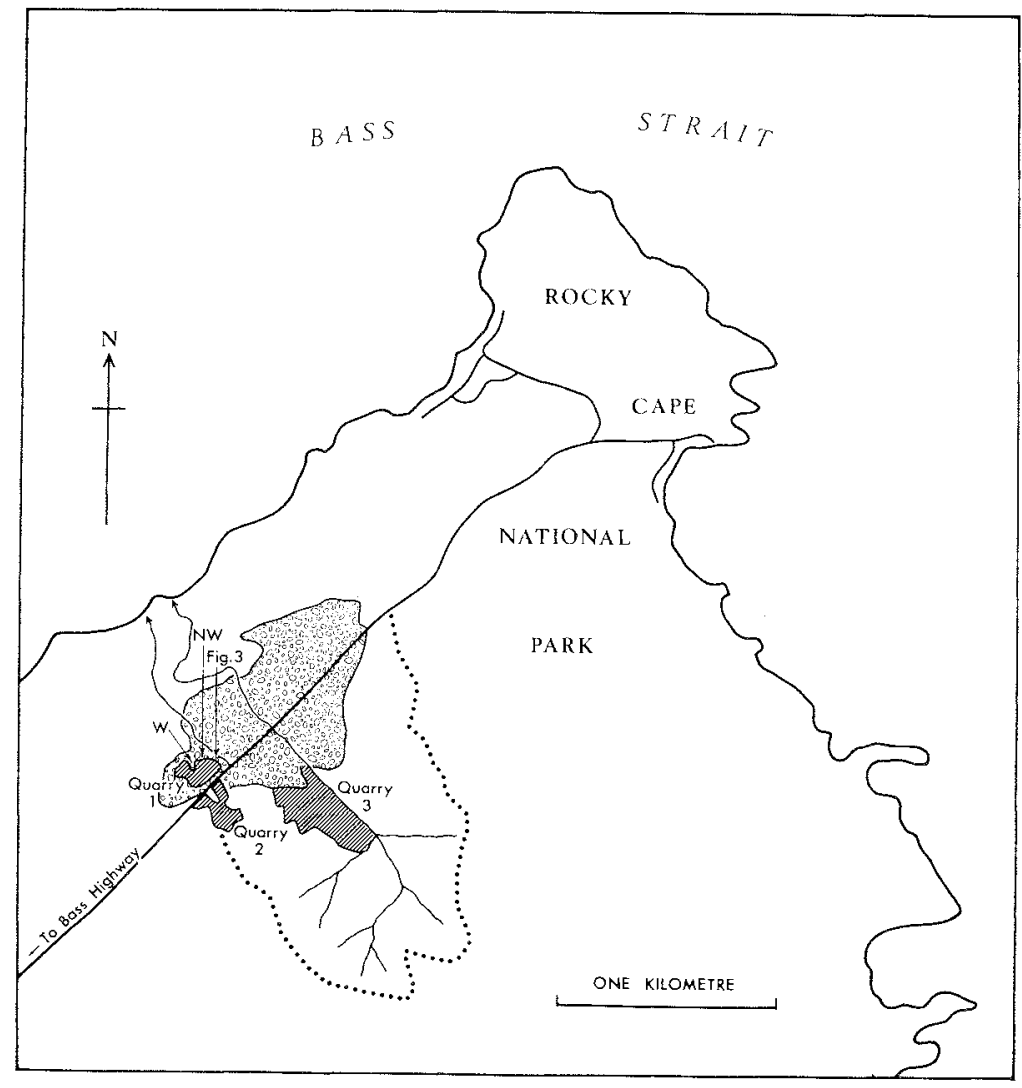

FIG. I - Location of Rocky Capo Catchment 
Eric A. Colhoun

The surface of the fan declines from $110 \mathrm{~m}$ to $28 \mathrm{~m}$. The periphery slopes at 14 degrees to a rock terrace that is thinly mantled with gravel on its upper part and consists of jagged outcrops of quartzite on its seaward side. The rock terrace, which continues for a short distance beneath the fan gravels, is probably a surface of marine abrasion developed during part of the Last Interglacial. Holocene dune sands occur between HWMST and $4 \mathrm{~m}$ (fig. 2).

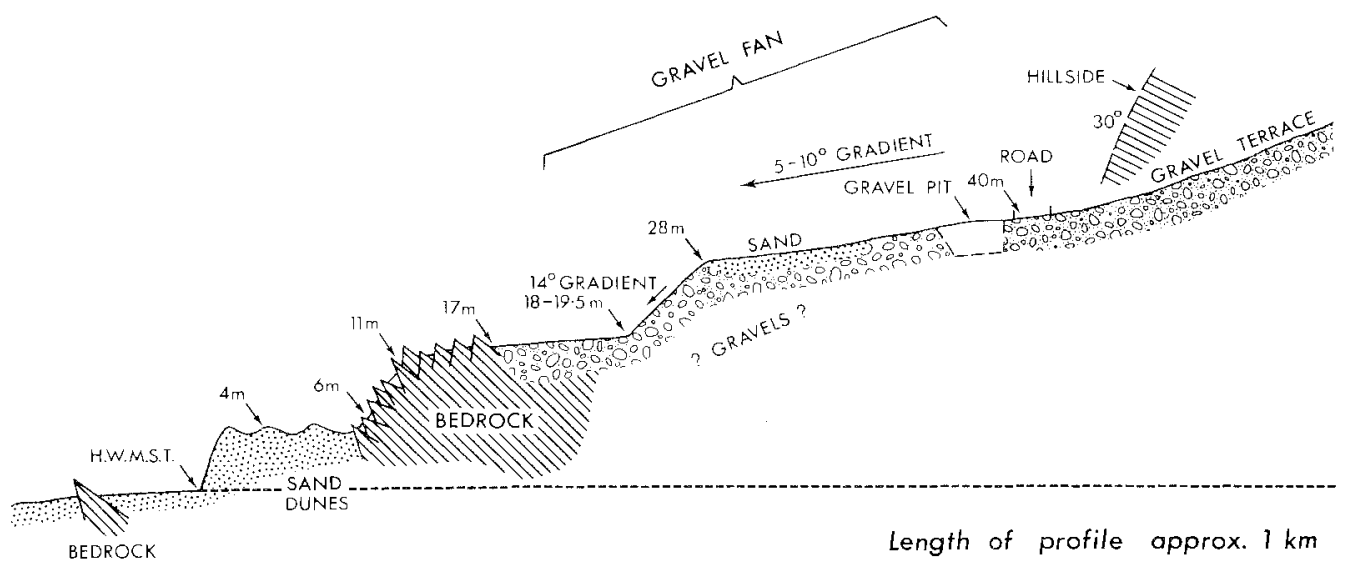

FIG. 2 - Profile from the valley to West Bay across the alluvial fan (surveyed by Stephens and van de Geer

The stratigraphy of the deposits exposed in the quarries at Rocky Cape is summarised in table 1 .

Several aspects of the sediments that form the slope deposits and fan gravels require further discussion.

The surface $0.5-0.75 \mathrm{~m}$ of peaty sand is widespread on the lower slopes and surfaces of the area. It has probably been formed during the late llolocene by the aeolian transport of fine sand from the dunes and beaches of West Bay onto the surface of the heath vegetation which facilitated its accumulation.

The upper series of slope deposits exposed in quarries 2 and 3 consists of sharpedged quartzite fragments that have been derived from the subjacent bedrock. The shape of the 20-150 $\mathrm{mm}$ fracture fragments is largely determined by the fractured nature of the bedrock but the form and structure of the deposits is identical with congelifractate deposits of periglacial origin. Where the upper quartzite slope deposits have overlain the indurated surface of the lower quartzjte slope deposits or the quartzite bedrock prior to quarrying, the surface of contact has been locally striated and shaven off by the downslope movement of the materials. Locally the lownslope movements have produced small drag-folds in the underlying quartzite.

Between 0.5 and $1.0 \mathrm{~m}$ from the surface of these deposits five wedge-shaped 
TABLE 1

LATE QUATERNARY DEPOSITS AT ROCKY CAPE

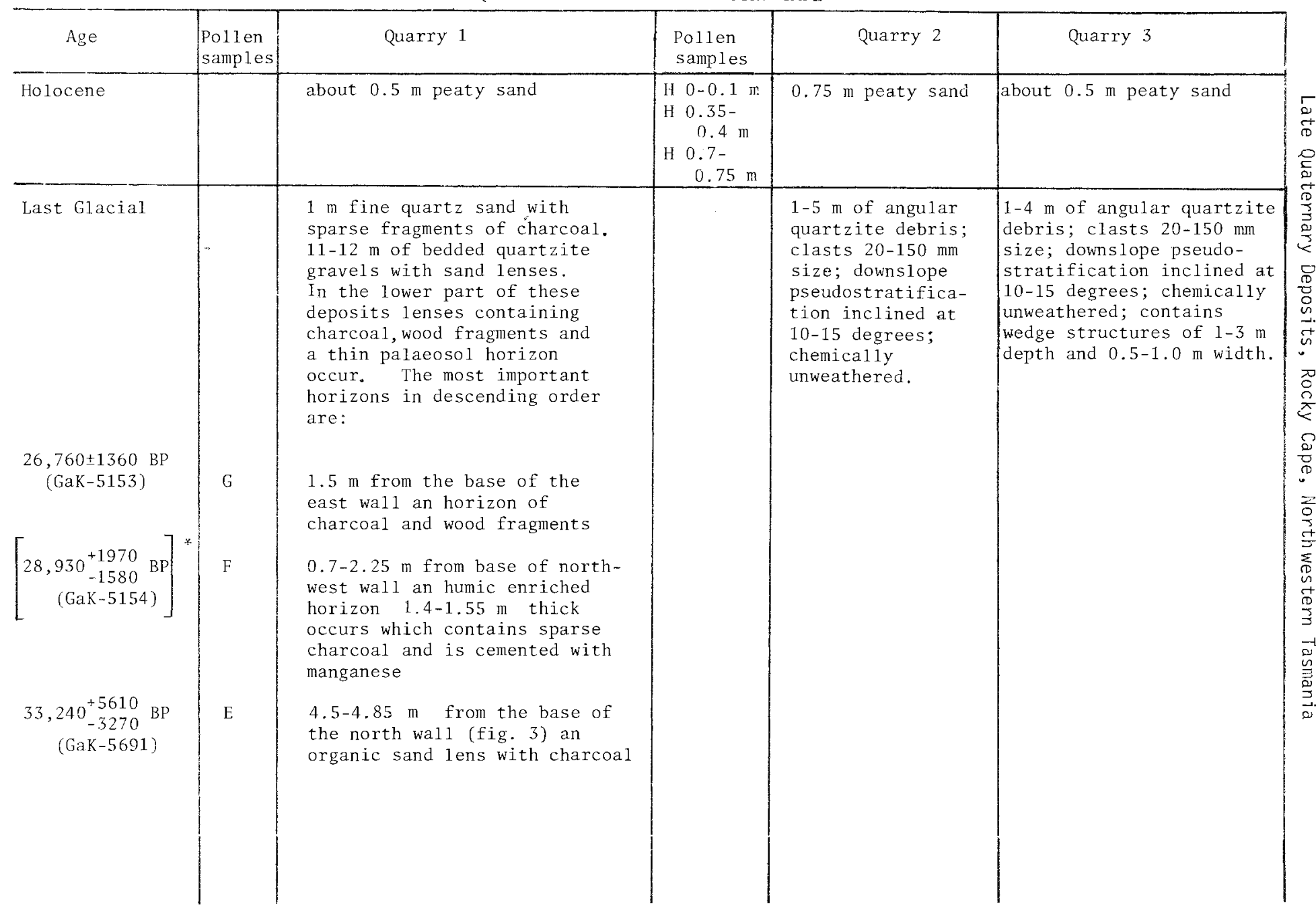




\begin{tabular}{|c|c|c|c|c|}
\hline $\begin{array}{c}24,090 \pm 1030 \mathrm{BP} \\
(\mathrm{GaK}-5155) \\
\\
32,350^{+3680}-2510 \mathrm{BP} \\
(\mathrm{GaK}-5690)\end{array}$ & $\begin{array}{l}\mathrm{C} \\
\mathrm{B}\end{array}$ & $\begin{array}{l}2.3-2.78 \mathrm{~m} \text { from the base } \\
\text { of the north wall a fossil soil } \\
\text { with roots in growth position } \\
\text { occurs in association with } \\
\text { charcoal and charred wood } \\
1.5-1.6 \mathrm{~m} \text { from the base of } \\
\text { the north wall an organic } \\
\text { sand } 1 \text { ens with sparse charcoal } \\
1.1-1.2 \mathrm{~m} \text { from the base of the } \\
\text { north wall an organic sand } 1 \text { ens } \\
\text { with charcoal } \\
0-0.25 \mathrm{~m} \text { from base of north wall } \\
\text { an organic sand horizon with } \\
\text { sparse charcoal } \\
\text { The base of the fan gravels is } \\
\text { not exposed }\end{array}$ & & \\
\hline $\begin{array}{l}\text { Pre-Last } \\
\text { Glacial (?) }\end{array}$ & & & $\begin{array}{l}\text { Podzol soil profile } \\
0.5 \mathrm{~m} \text { thick occurs } \\
\text { on } 0.5 \text { to } 1.0 \mathrm{~m} \text { of } \\
\text { strongly indurated } \\
\text { angular and } \\
\text { chemically un- } \\
\text { weathered quartzite } \\
\text { debris; clasts } 20- \\
150 \mathrm{~mm} \text { size with a } \\
\text { downslope pseudo- } \\
\text { stratification of } \\
\text { lo-is degrees } \\
\text { inclination. }\end{array}$ & \\
\hline
\end{tabular}

${ }^{\star}$ From an adjacent part of the west wall of Quarry 1 
structures occur 5-10 $\mathrm{m}$ apart and vary from $1-3 \mathrm{~m}$ in depth and from $0.5-1.0 \mathrm{in}$ width (plate 1). The quartzite fragments within the wedge structures have had their long axes reoriented so that they are parallel with the margins of the wedges and almost at right angles to the long axes of the fragments in the slope deposits. In 1965 N. Stephens (pers. comm), recorded a similar wedge structure in the alluvial fan gravels of Quarry 1. The wedge began beneath the surface metre of fine sands and penetrated the underlying gravels to $1.5 \mathrm{~m}$ depth.

While the wedge structures resemble ice wedge pseudomorph forms in many respects and definitely occur intraformationally within the fractured quartzite slope deposits, their location on a slope of 10-15 degrees inclination and the absence of any records of ice wedge pseudomorphs from much more likely sites in Tasmania makes such an explanation unlikely. The way in which the quartzite fragments are arranged within the wedge structure as a secondary fabric approximately at right angles to the fabric of the slope deposits indicates that some force has selectively disturbed the particles in the wedges after they were primarily deposited. The wedges do not appear to have resulted from collapse or transport of part-

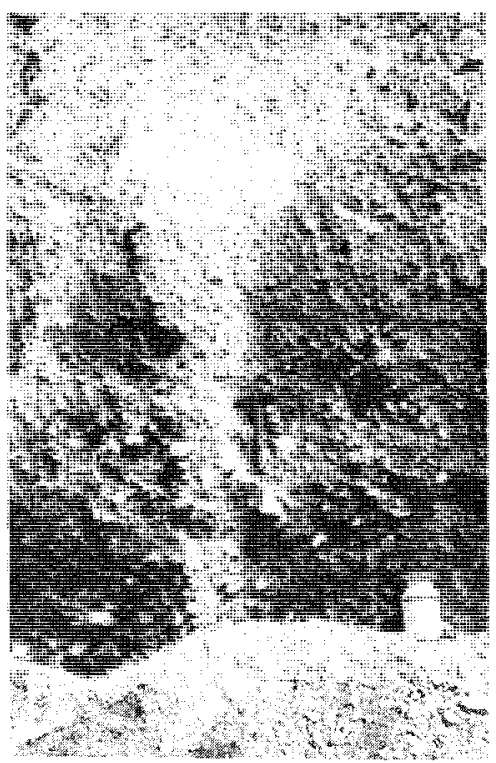

PLATE 1 - Wedge structure in the quartzite slope deposits at Quarry 3 at Rocky Cape icles into tension cracks produced by desiccation of the ground surface or simply to pressures induced by wetting and drying of the ground as can occur in areas of expandable materials (Black 1976). The non-expandable nature of the coarse quartzite detritus and the reorientation of the particles without any addition of extraneous materials of different form or texture, as would be expected if a void space were infilled, suggests that the only forces involved operated within the surface layers of the ground without the development of an open crack. It is possible that occasional severe seasonal freezing and subsequent thawing of moisture in the ground surface under colder and more continental climatic conditions could have produced the pressures that formed these wedge structures.

The alluvial fan gravels exposed in Quarry 1 have been derived mainly from the upper series of slope deposits (fig. 3). They consist of bedded poorly to moderately sorted deposits of medium to coarse cobbles of $50-200 \mathrm{~mm}$ size with a medium to coarse sandy matrix that varies from 50 to 70 per cent of the deposit (plate 2). The beds dip radially outwards from the apex of the fan at angles of 5-10 degrees inclination, and increasing amounts of sand and silt occur on the periphery of the fan. 
Eric A. Colhoun

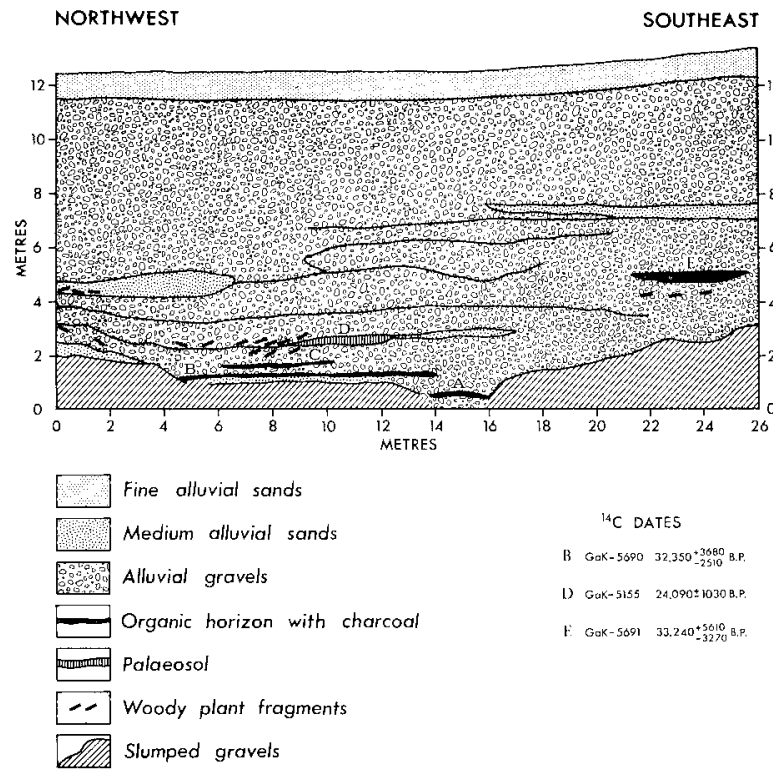

FIG. 3 - Alluvial gravels in northern wall of Quarry 1

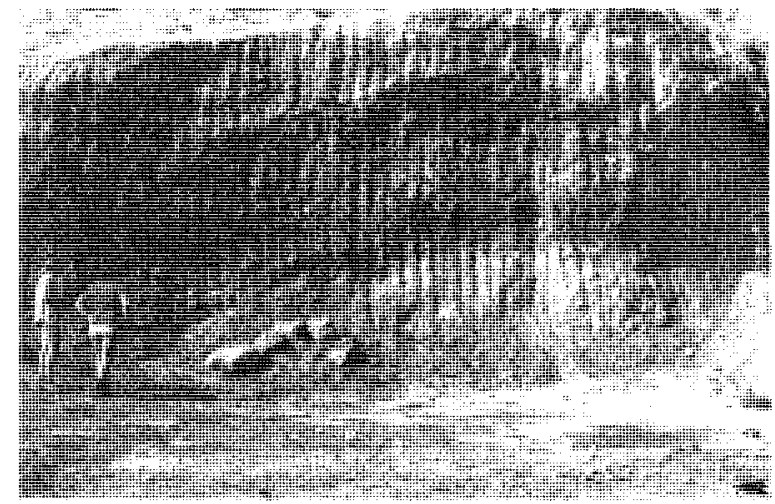

PLATE 2 - Quartzite alluvial fan gravels in Quarry 1 at Rocky Cape showing the fossil soil horizon 
The deposits vary between a light grey (7.5YR 8/1) and brownish-grey (10YR 4/1) colour, but are locally dull orange (7.5YR 6/4) or brownish-black (7.5YR 2/2) in colour where stained with iron and humic or manganese materials respectively (Standard Soil Color Charts 1967).

The wood and most of the charcoal fragments within the fan gravels occur in the lower five metres. Some of the wood fragments have been abraded through transport by floodwaters which eroded the slope deposits from the middle part of the valley and deposited them in the fan gravels at the valley mouth. Most of the lenses that contain significant amounts of charcoal. and the humic horizons do not represent ground surface accumulations but have resulted from the redeposition of wood, charcoal and humic materials derived by erosion of a formerly stable land surface(s) or temporarily stable surfaces in the catchment. The partially burnt character of much of the wood and the abundance of charcoal suggests that the initial erosion of the catchment which produced the materials may have occurred after heavy and frequent firing of the catchment. Much of the humic staining in the alluvial gravels is due to later solution and precipitation of colloidal organic matter in humus-iron complexes by groundwater percolation. Only the 0.25-0.4 $\mathrm{m}$ thick and $3.6 \mathrm{~m}$ long exposure of organic sandy-silt palaeosol as horizon D certainly represents the development of a surface of temporary stability. The in situ roots and sharp upper boundary of the soil clearly indicate a significant break in the deposition of the fan gravels at this point. However, an hiatus in accumulation need not necessarily have occurred over the entire surface of the fan at this time.

In Quarry 2 a podzol soil profile has been developed on the surface of the lower slope deposits and beneath the upper slope deposits. The podzolised surface probably passes under the fan gravels and although it is not a deeply developed profile it nevertheless seems to represent a significant break in time between the deposition of the lower and upper series of slope deposits. The fact that the profile is developed on the surface beds of the lower indurated slope deposits and not within the base of the upper slope deposits indicates that it is not merely an horizon which has been enriched with humus-iron compounds precipitated from groundwater perched on the compacted surface, but represents the remnant of a ground surface which was exposed to processes of podzolisation after the deposition and induration of the lower slope deposits had been completed.

The lower series of slope deposits although thinner has identical characteristics with the deposits of the upper series except for the high degree of induration and the absence of wedge structures. The deposit appears to be a congelifractate derived from the quartzite during an earlier phase of landscape instability induced by cold climatic conditions. Partial erosion of the surface of the lower slope deposits indicates that they, like the quartzite of the upper slopes, contributed to the formation of the upper slope deposits and indirectly to the alluvial fan gravels.

\section{DATING}

Dating of the sequence of organic horizons in the lower part of the fan gravels has proved problematical. Some of the dates have large standard errors and the assay from horizon $D$ appears at first sight to be younger than the assays from the overlying horizons $\mathrm{E}$ and $\mathrm{G}$. An additional assay has been obtained for wood deposited $0.5 \mathrm{~m}$ above the floor of Quarry 1 on its seaward or western wall. The assay was $28,930 \pm 1970$ BP (GaK-5154) and the bed that contained the wood occurred at approximately the same level as horizon $F$ in the northwest wall. llowever, owing to rapid lateral and vertical variations in the fan gravel deposits precise correlation could not be obtained.

If the probability limits of the time ranges of the assays are examined then at $1 \sigma$ there is no overlap of GaK-5155, at 20 there is time overlap with assays 5153 and 5154 , and at 30 with a11 the assays. If, however, the data is tested using the 
Eric $A$. Colhoun

relationship of the arithmetic difference between the assays and the square root of the sum of the squares of each standard deviation, as recommended by Polach and Golson (1966), it is found that all the arithmetic differences are 1 and 2 times the latter values. Both techniques indicate that the value of $24,090^{\circ}+1030$ BP (GaK-5155) for the palaeosol cannot be considered as significantly different from the other assays obtained on wood and charcoal from the lower part of the fan gravels. As this assay has the lowest standard deviation values of the assays and is associated with a stable ground surface, it is probably the most accurate of the determinations. Also, since the assays below and above this 1 evel were made on detrital wood and charcoal fragments derived by erosion of the ground surface(s) in the catchment the age of the wood and charcoa1 fragments on any horizon may predate the age of its deposition but are unlikely to postdate it.

The ${ }^{14} \mathrm{C}$ assays at Rocky Cape, therefore, may be interpreted as indicating that between approximately 44,000 and 22,000 BP (20 limits) erosion of the catchment destroyed a former stable land surface. Later and areally restricted stable surfaces of short duration as demonstrated by the palacosol of horizon D were also destroyed by crosion while the lower part of the fan gravels accumulated. Due to the large $\sigma$ values of the older assays it is likely that these events occurred mainly during the latter half of the time range between about 33,000 and 22,000 BP rather than during the earlier part.

The absence of wood and charcoal fragments in the upper part of the alluvial fan gravels suggests that the early period of intermittent severe erosion from the catchment with deposition on the fan surface was succeeded by a more intense phase of erosion and deposition, when the upper series of slope deposits were highly mobile and the fan surface was not even temporarily stabilised by shrub or tree vegetation likeiy to yield wood or charcoal fragments to the accumulating fan deposits. The appearance of small finely divided particles of charcoal in the surface metre of fine sands may reflect a return to slightly more stable ground surface conditions at the end of the Last Glacial. This charcoal may possibly relate to firing of the catchment by early aboriginals in the Rocky Cape area (Jones 1968) but it could be of natural origin. Unfortunately not enough charcoal could be obtained for dating.

\section{POLLEN ANALYSIS}

Samples A-G were collected from the organic horizons in the fan gravels and samples H $0.1 \mathrm{~m}, \mathrm{Hl} 0.35-0.4 \mathrm{~m}$ and $\mathrm{H}$ 0.7-0.75 m were taken from the overlying Holocene peaty sand deposits. In addition pollen trap samples were collected from the middle part of the catchment southeast of Quarry 3 to assess the modern pollen rain. The samples were processed by the Faegri and Iversen technique (1964) and relative counts based on sums of 300 grains of all pollen including the spores of Dickecnia and cyathea were made. The pollen types were identified by comparison with reference slides of modern pollen in the collections of the Geography and Botany Departments of the University of Tasmania. The taxonomic nomenclature follows Curtis (1956, 1963, 1967). The percentages are given in table 2.

Because of the problems associated with transported organic materials that contain pollen and the pollen content of fossil soils (Grichuk 1967; Riezcbos and Slotboom 1974; Dimbleby 1957, 1961a, 1961b; Havinga 1974) only 1imited results were expected. However, it was hoped that some indications of how the groups of plants composing the vegetation varied during the period when the lower part of the fan gravels was deposited might be obtained. It was also hoped that sone general indications of how the Holocene vegetation changed at Rocky Cape could be determined. The most important pollen grcips have been represented according to stratigraphic position in figure 4 . Although it is recognised that any horizon may contain derived pollen, it is probable that most of the tree and shrub pollen on each horizon was transported from the catchment with the wood and charcoal fragments and deposited at approximately the sime time. 
TABLE 2

POLLEN PERCENTAGES FROM ROCKY CAPE

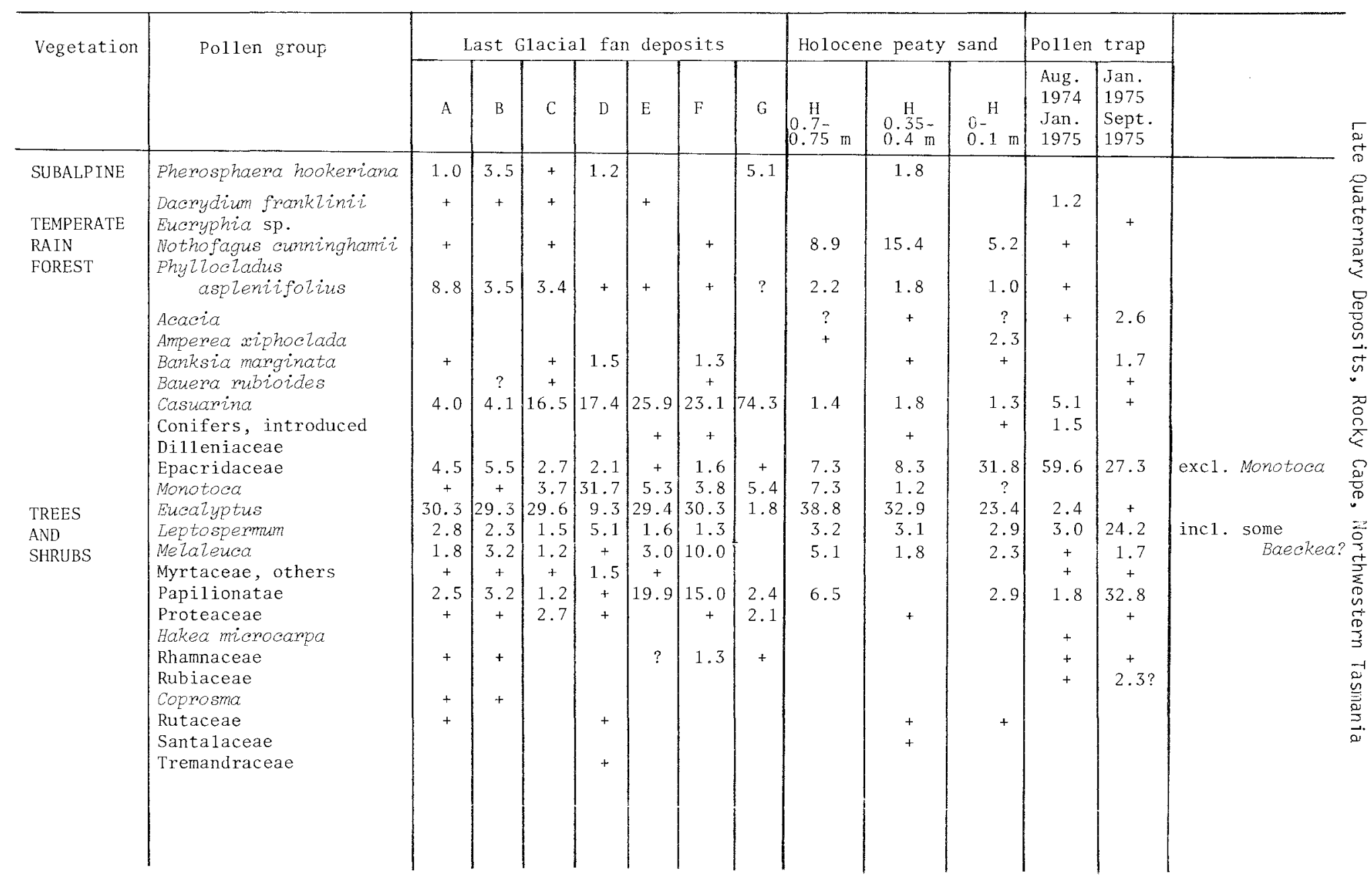




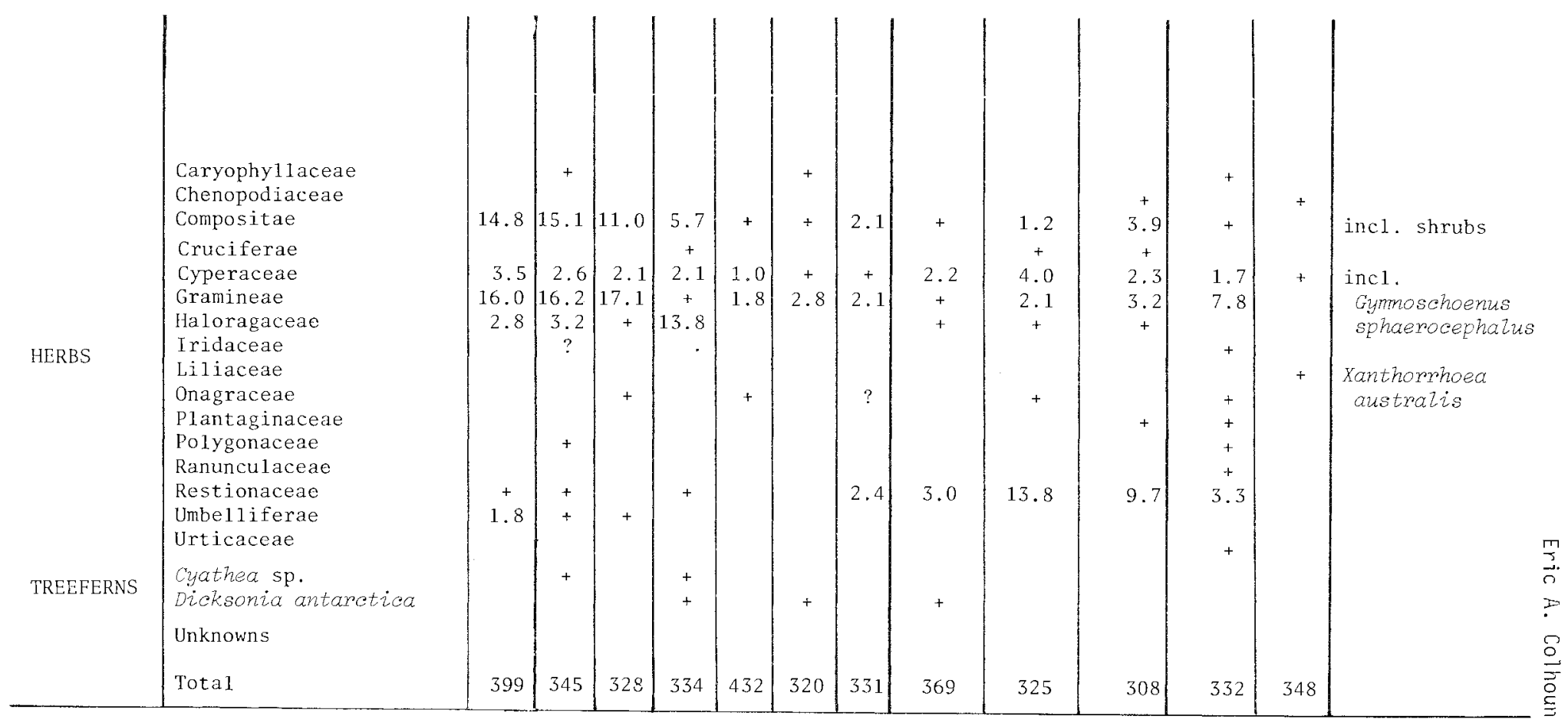

$+<1 \%$ 
It is unfortunate that the ${ }^{14} \mathrm{C}$ dates do not indicate more precisely when each horizon was deposited.
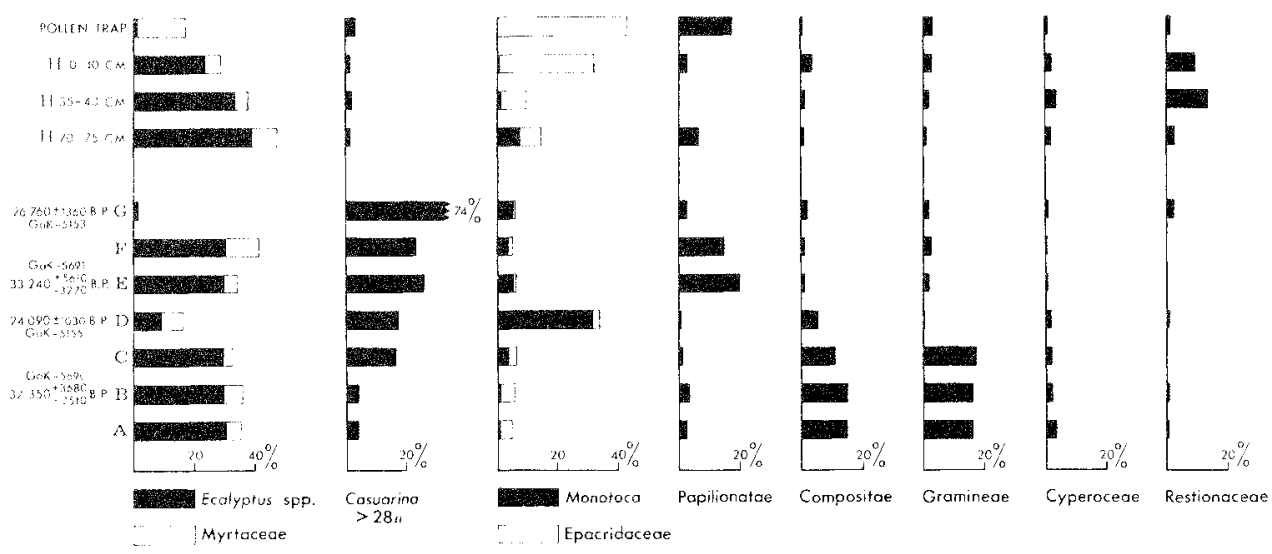

FIG. 4 - Stratigraphic trends of some pollen groups (Pollen trap values are the mean of two samples, table 2)

The present vegetation of the Rocky Cape peninsula is a heath association but it varies from patches of Eucalyptus woodland through lowland scrub and heath to local areas of herbland (Jackson, in Specht et a.. 1974). In the catchment the vegetation varies from grassy-sedge-heath with Gymoschoenus sphaerocephalus, Restionaceae, Xanthorphoea austratis, Gramineae and epacxidaceous species to open-scrub-heath dominated by Sprengelia incamata with Lencopogon, Banksia marginata, Leptospermm, Papilionatae, Casuamina, Acacia, and cccasional Eucalyptus saplings. This vegetation is reflected in the modern pollen rain.

The graph showing the stratigraphic trends of some of the pollen groups (fig. 4) indicates a marked decline of Eucalyptus pollen and a marked increase in pollen of Epacridaceae, especially Leveopogon and Sprengelia incomata, in horizons H 0.7-0.75, $\mathrm{H}$ 0.35 -0.4 and $\mathrm{H} 0-0.1$ of the Holocene peaty sand. The changes indicate reduction in the extent of Eucazyptus forest and its replacement by open-scrub and heath. This change is probably the result of aboriginal firing of the area during the Middle and Late Holocene.

The Temperate Rain Forest component (table 2) of all horizons is considered to result from long distance transport of pollen to the site, but the relatively high percentages of hothofagus cumninghami in the peaty sand suggest a more proximal source to the south during the Holocene than during the Last Glacial.

The most important components of the glacial age horizons A-C are Eucalyptus spp. (about 30\%), Gramineae $(16-17 \%)$ and Compositae $(11-15 \%)$, with significant quantities of Cosuamina and Epacridaceae. These groups suggest that the vegetation was an open Eucalyptus forest (Spccht 1970). In the fossil soil of horizon D Eucalyptus is relatively decreased by the high value (31.7\%) for Monotoca, but Casuamina maintains its relative increase. Eucazyptus maintains about 30 per cent on horizons $E$ and $F$ but markodly decreases to 1.8 per cent on horizon $G$. This decrease is partly due to the strong increase in Cacuarina but may also be a real decrease related to increased 
Eric A. Cothoun

conditions of surface instability in the catchment and on the fan.

Between horizons $\mathrm{C}$ and G Casuarina expands from 16.5 to 74.3 per cent and above horizon G Gramineae and Compositae decrease to less than 3 and 6 per cent respectively. The sequential changes suggest that the understory of the open Eucazuptus forest gradually altered from a predominantly grass and herbaceous cover to a heath-shrub understory of Casuamina, Epacridaceae and Papilionatae.

\section{CONCLUSIONS ON ORIGIN AND PALAEOENVIRONMENTAL SIGNIFICANCE:}

The lower series of quartzite slope deposits in Quarry 2 are the oldest surficial deposits exposed at Rocky Cape. Although the angular form of the fragments comprising these deposits may be partly predetermined by initial structures in the quartzite, the angular shapes of the chemically unweathered fracture fragments, the downslope stratified structure, and the highly compacted nature of the deposit, which is not cemented by iron and manganese that could have formed rapidly in the acid soil water environment, suggests that the deposit was largely formed by frost shattering of exposed rock slopes at a time which considerably preceded the formation of the fan gravels and upper slope deposits. While it is possible that such deposits could have been formed by strong frost action at the time of maximum glaciation in the Forth, Mersey and Leven valleys of northwestern Tasmania there is no way of directly correlating the slope deposits with the Forth GIaciation (Colhoun 1976). Their geographic location, stratigraphic position, and separation from the upper series of slope deposits by the development of a weak podzol soil profile on their surface would, however, support the interpretation that they were formed during cold climatic conditions which preceded the Last Glacial Stage.

The alluvial fan gravels exposed in Quarry 1 at the mouth of the catchment probably began to accumulate about or slightly after 33,000 BP and continued to accumulate throughout the Last Glacial Stage. The occurrence of charcoal and organic rich horizons demonstrate both stripping of the soil and surface organic debris from the catchment and its deposition within the lower part of the fan gravels. This erosion was probably subsequent to frequent heavy firing of the catchment. The thin humic palaeosol indicates a temporary period or local surface of stability on the fan. Pollen analysis of the organic deposits indicates that open Eucalyptus forest with a grass-shrub understory occupied the area while the lower part of the fan gravels accumulated.

The upper part of the alluvial fan gravels (above horizon E, fig. 3) in Quarry 1 mainly accumulated after about $22,000 \mathrm{BP}$ and before 10,000 BP when strong erosion of unstable slope detritus from the catchment supplied the material for deposition on the fan surface. The absence of organic or buried soil horizons from the unconsolidated but presently stable, upper scries of slope deposits in quarries 2 and 3 suggests that these deposits should be correlated with the upper organically sterile sequence of fan deposits. The development of intraformational wedge structures between one and three metres of the surface in both formations supports this correlation. The fossil wedge structures have been developed as a result of ground surface pressures that may have been caused by seasonal decp freezing of the ground surface. The angular shapos of the chemically unweathered fracture fragments and the downslope stratified structure strongly supports the interpretation that they were formed under much colder climatic conditions than at present, during which strong winter frosts would pliysically fracture the exposed quartzite rock and would facilitate the downslope transport of the debris by gelifluction processes.

Although there is no direct palaeobotanical evidence to indicate the nature of the vegetation in the catchment while these deposits were being formed the nature and quantity of the slope deposits indicates that the catchment could not have been forested, and was probably an open environment in which grasses, herbs and low shrubs formed the bulk of the vegetation. 
Late Quaternary Deposits, Rocky Cape, Northwestern Tasmania

The field evidence from Rocky Cape indicates that the alluvial fan gravels and the upper series of slope deposits were mainly formed during the period of maximum cold in the Last Glacial Stage when the glaciers of western and central Tasmania were at their maximum extent (about 18,000 BP), when preexisting soil and regolith were mobilised, when freshly derived fragmental slope deposits were formed and moved downslope on many steep slopes in northwestern Tasmania (Colhoun 1976a), and when open non-forested environments were probably much more widespread on low ground than at present (Macphail 1975; Colhoun 1977a).

\section{ACKNOWLEDGEMENTS}

I wish to acknowledge the assistance of G. van de Geer, W.R. Sigleo and R.J. Wasson in discussion of this site, the University of Tasmania for financial assistance towards the field work, and the Australian Research Grants Committee for financing the ${ }^{14} \mathrm{C}$ dating. I should like to thank Professor W.D. Jackson for the use of the pollen reference collection of the Botany Department, University of Tasmania, and Professor N. Stephens for permission to modify and use Figure 2.

\section{REFERENCES}

Banks, M.R. 1965: Geology and mineral deposits. In Davies, J.L. (Ed.)., AtZas of Tasmania, Lands and Surveys Department, Hobart, 12-17.

Black, R.F., 1976: Periglacial festures indicative of permafrost: Ice and soil wedges. Quat. Res., 6, 3-26.

Colhoun, E.A., 1975: A Quaternary climatic curve for Tasmania. Conference Paper at Australasian Conference on Climate and Climatic Change.Monash University, 7-12 December, $40 \mathrm{pp}$.

, 1975: The glaciation of the Lower Forth Valley, northwestern Tasmania. Aust. Geogr. Stud., 14 (2), 83-102.

, 1977a: The Late Quaternary environment of Tasmania as a backdrop to Man's occupance. Rec. Q. Vict. Mus. Launceston in press.

, 1977t: A sequence of Late Quaternary deposits at Pipe Clay Lagoon, southeastern Tasmania. Pap. Proc. R. Soc. Tasm., this volume.

- 1977c: The Remarkable Cave, southeastern Tasmania: its geomorphological development and envirommental history. Pap. Proc. R. Soc. Tasm., this volume.

Curtis, W.M., 1956, 1963, 1967: THE STUDENT'S FLORA OF TASMANIA. 3 vols. Govt. Printer, Hobart.

Dimbleby, G.W., 1957: Pollen Analysis of Terrestrial Soils. New Phytoz, 56, 12-28. , 1961a: Soil pollen analysis.J. Soiz Sei., 12 (1), 1-11. , 1961b: Transported material in the soil profile. J. Soiz Sei., 12(1), $11-22$

Faegri, K. and Iversen, J. 1964: TEXTBOOK OF POLLEN ANALYSIS. 2nd Edn., Munksgaard, Copenhagen.

Grichuk, M.P., 1967: The study of pollen spectra from recent and ancient alluvium. Rev. Pazaeobotan. Palynoz., 4, 107-12. 
Eric A. Colhoun

Havinga, A.J., 1974: Problems in the interpretation of pollen diagrams of mineral soils. Geol. Mijnboraw, 53(6), 449-53.

Jones, R., 1968: The geographical background to the arrival of Man in Australia and Tasmania. Areh. Phys. Anthrop. Oceconia, 3, 186-215.

Macphai1, M.K., 1975: Late Pleistocene environments in Tasmania. Search, 6(7), 295-300.

Polach, H.A. and Golson, J., 1966: COLLECTION OF SPECIMENS FOR RADIOCARBON DATING AND INTERPRETATION OF RESULTS. Australian Institute of Aboriginal Studies Manual No. 2.

Riezebos, P.A. and Slotboom, R.T., 1974: Palynology in the study of present day hillslope development. Geot. Mijnborw, 53(6), 436-38

Specht, R.L., 1970: Vegetation. THE AUSTRALIAN ENVIRONMENT. 4th Edn. CSIRO, Melbourne 44-67.

Specht, R.L., Roe, E.M. and Broughton, V.H., 1974: CONSERVATION OF MAJOR PLANT COMMUNITIES IN AUSTRALIA AND PAPUA-NEW GUINEA. Austr. Joum. Bot., Suppl. Series, 7, $667 \mathrm{pp}$.

STANDARD SOIL COLOR CHARTS, 1967 Fujihira Industry Co. Ltd., Tokyo. 